\title{
The Impact of Taxation on Economic Growth Using ARDL Approach: A Case Study of Pakistan
}

\author{
Sareer Ahmad * $\quad$ Majid Ali $^{\dagger} \quad$ Saleem Khan ${ }^{\ddagger}$
}

\begin{abstract}
This study intends to observe to investigate the taxation impact on economic growth of Pakistan by using time series data from 1980 to 2015. This study explore the short $\mathcal{E}$ long run effects of taxation on economic growth of Pakistan. Stationarity of the data checked through Augmented Dickey Fuller (ADF) test and then applied Autoregressive Distributed Lag (ARDL) model to check relations among the variables. Results of the study shows that taxes and exchange rate show negative but significant effect on economic growth in short run and long run. Life expectancy and trade liberalization have positive impact on economic growth in both periods. Thus, policymakers should focus on fiscal policy which is necessary to promote sustainable economic growth.
\end{abstract}

Keywords: Economic growth, Tax, ARDL, Fiscal Policy.

\section{Introduction}

Tax is the compulsory contribution by people to government treasury to meet the government expenditure for the welfare of common people of the country. Pakistan condition regarding tax collection is very worse. A varies studies conducted to investigate the relationship between tax and economic growth. Mostly economist explore negative relation between economic growth and taxes. Tax rate adversely affects economies and discourages work effort. Due to high tax rate the productive citizen of the country shifted to other countries where tax rate is low so it is a huge loss for economy of a country. High rate of taxes disturbs the price signals, and it reduce the incentives to invest for human and physical capital. If investment is more you will pay more. A country where the tax rate is very high the foreign investor can not want to invest their capital here because the profit maximization is low while the first and foremost aims of every investors is profit maximization. The local investors prefers to invest abroad where ease of doing business and low tax rate is available. So, the taxation structures matter a lot in affairs of economic growth.

The instruments of public policy i-e tax rate changes, have different types of implication in exogenous and endogenous growth theories. The neoclassical (exogenous) theorist explain that permanent changes in government policies do not have permanent effect on

\footnotetext{
*M.Phil Scholar, School of Economics, Quaid-e-Azam University, Islamabad. Email: sareereco3722@gmail.com

${ }^{\dagger}$ M.Phil Scholar, Department of Economics, Hazara University Mansehra, Pakistan.

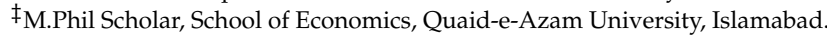


growth rate output. This predict that change in tax structure should have transitory impact only in long run (Ramsey, 1928; Solow, 1956). Such changes allows the country to move towards higher or lower level of economic activities but the path of new long run growth converge towards the path of old long run growth. The policymakers, academicians give more attention on tax structure. Firstly a large volume of tax revenue required for emerging and developing economies for efficient and smooth functioning of State at both national and international level. Globalization, the very basic foundation for goods and services in the most of economies (McNabb, 2018). Less developed countries facing more difficulties to maintain the taxation, due to competition. Secondly, tax structure and its collection create distortionary impacts on economies through tax burden. Thus, positive and negative impact of taxation made the "tax growth" relationship more complex and the taxation structure definite role in the process of economic development of an economies. Durusu-Ciftci, Gokmenoglu, and Yetkiner (2018) investigate the tax policy effects on economic performance. Corporation and income taxes both are the foremost tax instruments for governments irrespective of the level of developments of a country. In the formation of tax structure these two taxes have many implication in the economic growth of a country. Dackehag, Hansson, et al. (2012) studied that corporation and income taxes has negative relationship with growth performance.

In Pakistan FBR (Federal Board of Revenue) department is responsible for tax collection but the transparency of FBR has been questioned. Both rich and poor people are not willing to pay tax and they consider it as a burden, while paying taxes insecurity feelings are everywhere. However, the government of Pakistan failed to capture the upper class who not pay taxes but poor salaries individuals are forced to pay taxes. In countries like Pakistan where people have little regard for social welfare, they tried to evade direct taxes. They also do not pay taxes due to political patronage. So, the governments in such countries rely more on indirect taxes on commodities since these are difficult to evade. Indirect taxes from $62 \%$ of total tax revenue in Pakistan. This percentage is very low in developing countries. Developed countries depend more on direct taxes. Direct taxes from $38 \%$ of total tax revenue in Pakistan.

Most of the economists agree that high rate of taxes is not a beneficial for the growth of the economies. Each country collect revenue through varies sources live fees, sale tax, income tax, toll tax etc. Some of the countries increase taxes while some countries do not after their policies regarding taxation. Every type of tax policies discourages economic growth of a country (Engen \& Skinner, 1996). According to Clark (2008), that tax affect economic growth of a country \& wealth distribution. Author favors progressive taxation because they help to increase income equality. The fundamental component for every economic policy of a country in tax policies discourage productivity by reducing development and research. When tax rate is lower its means people \& organization are emphasis on development and research \& vice versa. Taxes will affect labor participation $\&$ reduce work incentive and also reduce economic growth of a country. Taxation policies can affect MPC (Marginal productivity of capital) because the investors will shift his asserts from where tax rate has high \& investment will start where tax rate is lower. 


\section{Literature Review}

Several studies in the existing literature have shown the existence of negative and positive relationship between taxation and economic growth but a few of them end up with mixed results. Ogbonna and Appah (2016) studied the relationship between tax reform and economic growth in Nigeria. Secondary data were used from time period 1994 to 2009 \& applied Granger causality test that showed that taxation reform have positive relationship with economic growth. However, to achieve economic development not only sufficient tax reforms. Barry (2008), investigated the relationship between economic growth \& taxation policy. For this purpose regression analysis was used on data from period 1964 to 2004. The researcher used endogenous growth shows negative relationship between economic growth and tax. Mahmood and Chaudhary (2013) studied the relationship between tax revenue and economic growth of Pakistan. Time series analysis has been used from period 1973 to 2008. The study concluded that taxes play a key role in the development of economic growth of a country.

Time series data have been used from period 1980 to 2015 and applied Autoregressive Distributed Lag (ARDL) model. Outcomes of the bound test showed that the variable taxes, trade, capital and economic growth are co-integrated. The statistical estimation of the econometric model specifies that there is a negative short run and long run relationship between taxes and economic growth in Jordan. The researcher suggest that fiscal policy is essential to promote sustainable in economic growth of Jordanian economy. McNabb (2018) explained that negative relationship exists between taxes and government expenditure because of increasing tax revenues. The researcher used panel data from time period 1975-2011 for twenty five (25) rich OECD (Organization for Economic Co-operation and Development) economies \& finds negative relationship between corporate income and economic growth. They concluded that highest tax rate affects economic growth negativity. However, for economic growth of country necessary lower tax rate to generate revenues and that can be spend on productivity. Neog and Gaur (2020) studied the short run and long run relationship between tax structure and economic performances of the Indian states. Data has been taken from period 1991 to 2016. For the analysis of the data panel regression method is used to verify the relationship between economic growth and taxation. Mean group estimation of the panel data indicates that commodity tax, income tax and service tax has negative effects while capital transaction tax and property tax have a positive effect on economic growth of the different states. The study concluded that for faster economic growth of Indian States. Government policymakers should give more attention to and income tax should be reduced. Engen and Skinner (1996) collected data from ten Canadian provinces from period 1977 to 2006. The results of the author show negative relation between tax rate \& economic growth of a country. The study explained that taxes reduction can boost economic growth of a country \& vice versa. Taxes affect the economic growth of a country through total factor productivity and factor accumulation. The higher tax rate discourages investors and affect the economic growth of a country.

Vartia et al., (2008) investigated that corporation tax has negative impact on OECD (Organization for Economic Co-operation and Development) countries. If suppose marginal 
tax rate and average tax rate, marginal tax rate is significant then average tax rate on labor supply and investment decisions. The empirical evidence prove that marginal tax rate and growth has negatively related, which explain that increasing marginal tax rate is related with compromises with the performance of growth of the economies. Haq \& Akram (2009) investigate the tax policies impact on economic growth of a country. The analysis of the study showed that the taxation policies which is implemented in South Asian economies have transitory impact only on their economic growth. However, the response function has shown that the policies of the government can affect the economic growth in transition path due to the steady state growth. Secondly, higher tax rate reduces the output level permanently but has no permanent effect on the level of output growth. The result of the study shows that the effect of tax rate fluctuations is transitory negative for short term in Pakistan and India while for Sri Lanka its positive effect for first year and then afterwards negative impact on economic growth. In all these countries tax rate are low as compared to advanced countries and all these countries heavily depends on foreign debt and bond financing due to low tax rates.

\section{Research Methodology}

The present study was conducted to investigate the impact of taxation on developing economies like Pakistan. Time series data has collected from period 1980 to 2015. The variable used in our model are Gross Domestic Product (\%), Trade liberalization, tax (\% of GDP), exchange rate, and life expectancy. Secondary data has been taken from varies issues of Economic Survey of Pakistan and World Development indicators. For data analysis Autoregressive Distributive Lag (ARDL model) is used.

Econometric framework of the model as follow:

$$
G D P=\alpha_{0}+\alpha_{1} \operatorname{Tax}+\alpha_{2} E X R+\alpha_{3} T L+\alpha_{4} L E+\mu
$$

Taking $\log$ of the data

$$
\ln G D P=\alpha_{0}+\alpha_{1} \ln T a x+\alpha_{2} \ln E X R+\alpha_{3} \ln T L+\alpha_{4} \ln L E+\mu
$$

The above Econometric equation converted into ARDL form:

$$
\begin{gathered}
\Delta \ln G D P_{t}+\alpha_{0}+\alpha_{1} \ln G D P_{t-1}+\alpha_{2} \ln \operatorname{Tax}_{t-1}+\alpha_{3} \ln \operatorname{Exr}_{t-1}+\alpha_{4} \ln T L_{t-1}+\alpha_{5} \ln L E_{t-1}+ \\
\sum_{j=1}^{n} \delta_{i} \Delta \ln G D P_{t-i}+\sum_{j=0}^{n} \theta_{i} \Delta \ln \operatorname{Tax}_{t-i}+\sum_{j=0}^{n} \eta_{i} \Delta \ln \operatorname{Exr}_{t-i}+\sum_{j=0}^{n} \gamma_{i} \Delta \ln T L_{t-i}+\sum_{j=0}^{n} \varphi_{i} \Delta \ln L E_{t-i}+
\end{gathered}
$$




\section{Results and Discussions}

\begin{tabular}{|c|c|c|c|c|}
\hline \multirow[t]{2}{*}{ Variables } & \multirow[t]{2}{*}{ Level/1st Diff } & \multicolumn{2}{|c|}{ ADF Test statistic } & \multirow[t]{2}{*}{ Conclusion } \\
\hline & & Trend & Drift & \\
\hline LN (GDP) & Level & -2.102 & $-2.839^{*}$ & $\mathrm{I}(0)$ \\
\hline LN (Tax) & 1st Diff & $-0.562^{*}$ & $-5.79^{*}$ & I (1) \\
\hline LN (EXR) & Level & -2.274 & $-1.821^{* *}$ & I (0) \\
\hline LN (Tax) & Level & -2.451 & -0.322 & - \\
\hline LN (LE) & Level & -1.432 & $-1.561^{* *}$ & $\mathrm{I}(0)$ \\
\hline LN (TL) & Level & $-4.563^{*}$ & $-3.451^{*}$ & I (0) \\
\hline
\end{tabular}

In table(I) indicate the stationarity of the variable through ADF( Augmented Dickey Fuller) test, which explained that Gross Domestic Product (GDP), life expectancy, exchange rate and trade liberalization are integrated of order zero $\mathrm{I}(0)$ while other variable tax $(\%$ of GDP) is integrated of order zero I(1).

Table 2

Autoregressive Distributed Lag estimates

\begin{tabular}{lcccc}
\hline Variable & Coefficient & Standard error & T-statistic & Probability \\
\hline C & 16.631 & 4.921 & -6.521 & 0.000 \\
LN (GDP-1) & 0.793 & 0.095 & 7.839 & 0.000 \\
LN (Tax) & -0.096 & 0.042 & -3.612 & 0.005 \\
LN (TL) & 0.995 & 0.047 & 0.0721 & 0.985 \\
LN (EXR) & -0.426 & 0.0531 & -6.157 & 0.000 \\
LN (LE) & -13.985 & 1.598 & 5.531 & 0.000 \\
R2 =0.989 & Adj R2 $=0.988$ & DW Stat=2.272 & F-stat $=5.14$ & \\
\hline
\end{tabular}

Table (II) indicates that GDP is the dependent variable while tax, life expectancy, exchange rate, and trade liberalization are the explanatory variables. In the above table variable tax shows negative relation but significant impact on economic growth of Pakistan. That is $1 \%$ increase in tax rate leads to decrease GDP by $0.096 \%$. Exchange rate negatively but significantly affecting growth rate of the economy; thus $1 \%$ increase exchange rate leads to decrease $0.246 \%$ in GDP. The life expectancy and trade liberalization have a positive impact on economic growth. Value of the coefficient of determination (R2) is 0.989 which indicates that $98 \%$ change in the explained variable is due to explanatory variables.

Table 3

Estimated long run Coefficient's using the ARDL model

\begin{tabular}{lcccc}
\hline Variable & Coefficient & Standard error & T-statistic & Probability \\
\hline C & -48.142 & 8.568 & -7.854 & 0.000 \\
LN (Tax) & -0.379 & 0.1095 & -2.859 & 0.015 \\
LN (TL) & 0.00591 & 0.0682 & 0.0526 & 0.965 \\
LN (EXR) & -0.6515 & 0.4412 & -3.988 & 0.000 \\
LN (LE) & 20.121 & 3.210 & 8.562 & 0.000 \\
\hline
\end{tabular}

The table (III) explained the long run relationship between the variables. Taxes and exchange rate have a negative relationship with economic growth and significant in long 
run, where increase life expectancy and trade liberalization lead to faster economic growth in long run.

\section{Conclusion and Policy Recommendation}

Results of the whole study shows that the taxes and exchange rate have negative impact and significant on economic growth both in short run and long run, while higher life expectancy leads to higher significant in economic growth in both short run and long run. Pakistan facing increasing socio-economic problems. Crime, political instability, terrorism, unemployment, poverty, low literacy rate, law and order situation and energy crisis are the main problems. Due to these reasons foreign investors feel insecure and they do not want to invest has capital in Pakistan, due to this reduce economic activities in Pakistan. All these factors badly effect the economic performance of any economies, and outcomes in the form of low Gross Domestic Product (GDP) level. Advanced countries focus on progressive taxation but unfortunately in Pakistan this situation is worse off \& more attention on indirect taxes. Pakistan depends on indirect taxes \& indirect taxes depends on the sale of goods and services, due to these types of taxes citizen badly affected. Pakistan collected $62 \%$ revenue from indirect taxes. So, Pakistan needs to increase direct taxes. In tax collection process political instability is a big hurdle, while law and order situation indirectly related with taxation. Stability of the economies means greater investment and availability of more jobs. The main factor of the fast economic growth to attract foreign investors into the country. Fiscal policy is the important tool that uses by government for maintain economic stability in the country. 


\section{References}

Dackehag, M., Hansson, A., et al. (2012). Taxation of income and economic growth: An empirical analysis of 25 rich oecd countries. Journal of Economic Development, 21(1), 93-118.

Durusu-Ciftci, D., Gokmenoglu, K. K., \& Yetkiner, H. (2018). The heterogeneous impact of taxation on economic development: New insights from a panel cointegration approach. Economic Systems, 42(3), 503-513.

Engen, E. M., \& Skinner, J. (1996). Taxation and economic growth (Tech. Rep.). National Bureau of Economic Research.

Mahmood, H., \& Chaudhary, A. (2013). Impact of fdi on tax revenue in Pakistan. Pakistan Journal of Commerce and Social Sciences (PJCSS), 7(1), 59-69.

McNabb, K. (2018). Tax structures and economic growth: new evidence from the government revenue dataset. Journal of International development, 30(2), 173-205.

Neog, Y., \& Gaur, A. K. (2020). Tax structure and economic growth: a study of selected Indian states. Journal of Economic Structures, 9, 1-12.

Ogbonna, G., \& Appah, E. (2016). Effect of tax administration and revenue on economic growth in nigeria. Research Journal of Finance and Accounting, 7(13), 49-58.

Ramsey, F. P. (1928). A mathematical theory of saving. The Economic Journal, 38(152), 543-559.

Solow, R. M. (1956). A contribution to the theory of economic growth. The Quarterly Journal of Economics, 70(1), 65-94. 